\title{
Conservation Status of Greater One-horned Rhinoceros (Rhinoceros unicornis) in Nepal: A Review of Current Efforts and Challenges
}

\author{
Pramod Ghimire \\ Agriculture and Forestry University, Faculty of Forestry, Hetauda, Nepal. \\ Email:pghimire@afu.edu.np
}

How to cite this paper: Ghimire, P. (2020). Conservation Status of Greater One-horned Rhinoceros (Rhinoceros unicornis) in Nepal: A Review of Current Efforts and Challenges. Grassroots Journal of Natural Resources, 3(1): 1-14. Doi:

https://doi.org/10.33002/nr2581.6853.03011

Received: 15 January 2020

Reviewed: 13 February 2020

Provisionally Accepted: 15 February 2020

Revised: 22 February 2020

Finally Accepted: 15 March 2020

Published: 31 March 2020

Copyright $\odot 2020$ by author(s) and

The Grassroots Institute.

This work is licensed under the Creative

Commons Attribution International

License (CC BY 4.0).

http://creativecommons.org/licenses/by/4.0/
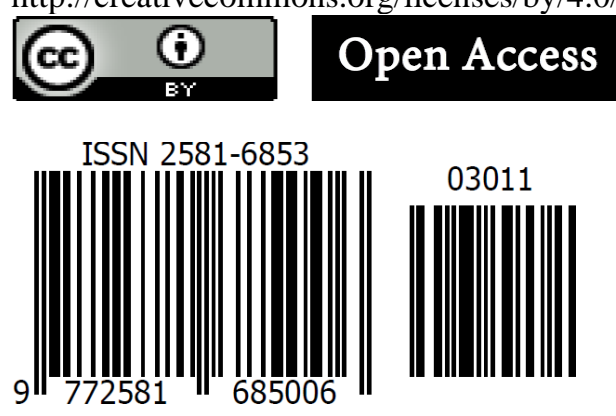

\begin{abstract}
The greater one-horned rhinoceros (Rhinoceros unicornis) is one of the iconic natural heritage of Nepal's rich biological diversity, backed by the commitment of the Government of Nepal to conserve this rare animal for now and future generations. It is not only important for conservationists due to its ecological value, but it also holds a universal appeal for ordinary people. Over the decades, the Government of Nepal, supported by national and international conservation partner organizations and the local communities, has significantly contributed to the conservation of this iconic species. Nepal's rhino population has increased by $45 \%$ between the year 2005 and 2015. There are now 645 rhinos in Nepal, marking an increase of 111 rhinos from the 534 recorded in the last census in 2011. These numbers reflect the success of conservation efforts for this species and are a result of improved rhino protection measures, and management of habitat. Though the population of one-horned rhinos has increased significantly over past years in the country, the protection of the rare wildlife species has remained a challenging job. Habitat loss and fragmentation, increasing encroachment of forest areas, climate change, poaching, and increasing human-wildlife conflict are major challenges for protection of this rare species. This paper discusses the current status and distribution of greater one-horned rhinoceros, and potential challenges to conserve this flagship species in Nepal.
\end{abstract}

Keywords

Conservation, Flagship species, One-horned Rhinoceros 
Doi: https://doi.org/10.33002/nr2581.6853.03011

\section{Introduction}

The greater one-horned rhinoceros, also known as the Indian rhinoceros, lives in floodplain grassland and adjacent riverine forests of North India and Southern Nepal. Belonging to the Rhinocerotidae family, greater one-horned rhinoceros (henceforth rhino or rhinoceros) is among the highly threatened large mammals in South Asia and South East Asia (GoN, 2006; Rookmaaker et al., 2016). Once common in the floodplains of Indus, Ganga and Brahmaputra river systems between Indo-Pakistan border in the West and Indo-Burma border in the East including the lowland Terai $^{1}$ of Nepal, the greater one-horned rhinoceros is now confined in a few fragmented forest and grassland patches, mainly in the protected areas in India and Nepal (Rookmaaker et al., 2016).

Included in appendix I of the Convention on International Trade in Endangered Species of Wild Fauna and Flora (CITES) since 1975, rhinoceros is strictly protected by National Park and Wildlife Conservation Act (1973) in Nepal (GoN, 1973, 2006). At present, there are about 3,500 individual rhinoceros in 12 protected areas of Nepal and India (DNPWC, 2017). Over the last decade, conservation efforts had boosted the population of rhinoceros to rebound from extinction in Nepal. While the population of one-horned rhinos has increased significantly over past few years in Nepal, the protection of the rare wildlife species has remained a challenging task. Rhino population in Nepal is greatly threatened due to uncontrolled poaching, degradation and loss of available habitats. In the past few decades, various efforts have been implemented for the conservation of this endangered species by the Government of Nepal and other conservation partner organizations; yet we still have to guarantee the safety of its long-term survival (DNPWC, 2016, 2017). While encroachment of rhino habitat, climate change, decrease in grassland and food competition with livestock are a few enduring threats, a growing concern in recent years has been the poaching and increasing human-wildlife conflicts (DNPWC, 2016 and 2017; Sedhain and Adhikary, 2016; Pant et al., 2019). It is imperative, now more than ever, for Nepal to put appropriate policies and strategies into action for the long-term conservation of rhinos. We may lose the rhinoceros population of Nepal if we fail to act on time. This paper intends to present the current status and distribution of greater one-horned rhinoceros in Nepal and conservation efforts and potential challenges to conserve this iconic species in the national context.

\section{Materials and Methods}

This paper is based on the desk review of various published and unpublished literature from different sources including web-based resources. Literature from 1969 to 2019 was reviewed to identify conservation status and current effort to conserve the greater one-horned rhinoceros in Nepal. In addition, consultation was done with key personals of Ministry of Forest and Environment (MoFE) and Department of National Park and Wildlife Conservation (DNPWC), Nepal for better analysis. The information collected was systematically reviewed for logical discussion and conclusion.

\footnotetext{
${ }^{1}$ Terai: A low land region in southern Nepal and northern India that lies south of the outer foothills of the Himalayas, the Siwaliks hills and north of the Indo-Gangetic plain. The region lies at an altitude of $57 \mathrm{~m}$ to $300 \mathrm{~m}$ between Indian borders in the south and the outer foothills of Churia in the north.
} 
Doi: https://doi.org/10.33002/nr2581.6853.03011

\section{Results and Discussion}

\section{Global Distribution of Rhinoceros}

The rhinoceros belongs to the family Rhinocerotidae and it includes four genera, five species and eleven subspecies. Today, only five species of rhinoceros are surviving in the world. Out of them, three species, Greater one-horned rhinoceros (Rhinoceros unicornis), Javan rhinoceros (Rhinoceros sondaicus) and Sumatran rhinoceros (Dicerorhinus sumatrensis) are confined in Asia, while Black rhinoceros (Diceros bicornis) and White rhinoceros (Ceratotherium simum) are found in the African continent (Rookmaaker et al., 2016; DNPWC, 2017). Once abundant in Asia and Africa, rhinoceros are now battling for their survival due to heavy poaching and destruction of suitable habitats. All three species of Asian rhinoceros are now restricted to isolated patches of protected areas (Amin et al., 2006; DNPWC, 2017). Javan rhinoceros is the most critically endangered species with about 50 individuals left in the wild in Java island of Indonesia. Sumatran rhinoceros have also suffered a $50 \%$ population decline over the last 15 years due to indiscriminate poaching and habitat loss (Amin et al.,2006). The Sumatran rhinoceros populations remain in few protected areas of Indonesia and Malaysia with less than 100 individuals. There are about 3500 Greater one-horned rhinoceros in the wild currently distributed in India and Nepal (Rookmaaker $e t$ al., 2016; DNPWC, 2017). Because of the recent recovery of rhinoceros populations in India and Nepal, the species has been downlisted from endangered to vulnerable category (IUCN, 2008). Application of the same criteria to Nepal alone would result in an endangered classification and there is some debate that this down-listing was not appropriate given the increasing pressures on this species by way of poaching and habitat encroachment (DNPWC, 2009).

Populations of critically endangered black rhino declined dramatically in the $20^{\text {th }}$ century at the hands of European hunters and settlers. Between 1960 and 1995, black rhino numbers dropped by $98 \%$, to less than 2500 (IUCN, 2013). Since then, the species has made a tremendous comeback from the brink of extinction (i.e. $96 \%$ of decline population). Currently, black rhinoceros are found in Namibia, South Africa, Kenya, Tanzania and Zimbabwe. Small populations, i.e. less than 20, of black rhinoceros are found in Malawi, Swaziland and Zambia. At present, about 5055 black rhinoceros with three subspecies are surviving in the wild (IUCN, 2013). The white rhinoceros is the most abundant species found in South Africa, Botswana, Namibia, Kenya, Zimbabwe, Swaziland, Tanzania and Uganda. Small populations remain in Zambia, Malawi and Mozambique (Emslie, 2012). With numbers as low as 50 left in the wild in the early 1900s, the white rhinoceros has now increased to over 20000 and has become the most populous of all the rhinoceros species (Amin et al., 2006). Despite the population increase every year, there has been unprecedented rise in rhinoceros poaching since 2008, which may bring the species back into decline if poaching is not reduced.

\section{Distribution of the Greater One-horned Rhinoceros}

The Greater one-horned rhinoceros is the second largest of the five surviving species. The rhinoceros once ranged across the entire northern part of the Indian subcontinent, along the Indus, Ganges and Brahmaputra river basins, from Pakistan in the west to the Indo-Burmese border in the east, including parts of Nepal, Bangladesh and Bhutan (Rookmaaker et al., 2016). They may have also occurred in Myanmar, Southern China and Indo-China. But due to habitat loss for other land uses, climatic change, excessive hunting and trade for horns, the habitat range has gradually 
reduced. As a result, by the $19^{\text {th }}$ century, the rhinoceros were restricted only in the Terai grasslands of Southern Nepal and Northern and Eastern India particularly in Uttar Pradesh, Bihar, West Bengal and Assam. At present, their ranges have further declined and are confined in isolated pockets of protected areas in Nepal and North eastern India (Figure 1) (Thapa et al., 2013; Rookmaaker et al., 2016).

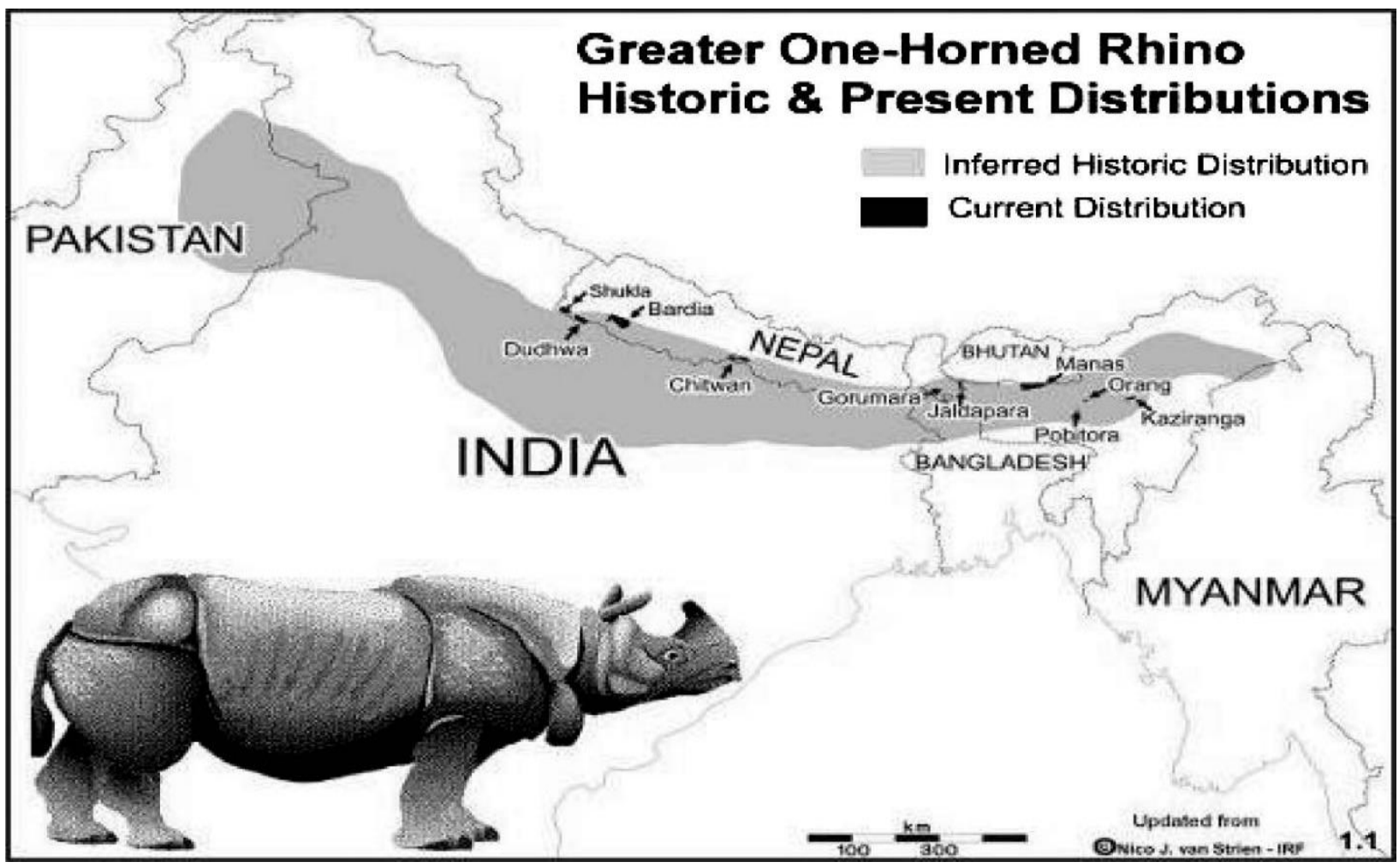

Figure 1: Map showing historic and present distributions of Greater one-horned rhinoceros (adapted from DNPWC, 2017)

Rhinoceros are now restricted to few protected areas in India and Nepal totaling about 3500 individuals in 12 protected areas. In India, majority are in Assam (Kaziranga, Pobitora and Manas National Parks and Orang Wildlife Sanctuary), in West Bengal (Jaldapara and Gorumara Wildlife Sanctuaries) and a few in Uttar Pradesh (Dudhwa National Park and Katerniaghat Wildlife Sanctuary). In Nepal, rhinoceros occur mainly in Chitwan National Park (CNP), Parsa National Park (PNP), Bardia National Park (BNP) and Shuklaphanta National Park (ShNP) and their surrounding forests (Figure 2). After the relocation of settlements (Ramauli Pratapur, Rambhori Bhatta area) in Parsa National Park and its extension to the East, this has created additional suitable habitats and rhinoceros from Chitwan have started colonizing the new habitats in Parsa National Park (DNPWC, 2017).

\section{Current Status and Distribution of Greater One-horned Rhinoceros in Nepal}

The Greater one-horned rhinoceros is one of the most studied large mammals in Nepal (Pradhan $e t$ al., 2008; Subedi, 2012). Tall floodplain Terai grasslands interspersed with riverine forests and wetlands are key habitats for rhinoceros (Dinerstein, 2003; Subedi, 2012). In Nepal, rhinoceros population was estimated over 800 individuals until 1950 in the Chitwan valley. The valley and its 
rich biodiversity were protected by the then ruling Rana regime for spot hunting. The area was also protected from outsiders since malaria was prevalent in the valley. Only a few Indigenous communities like the Tharus, who were known to be immune to malaria disease, were residing in the valley. The impact of their presence on valley's natural environment was negligible (Caughley, 1969; Laurie 1978).

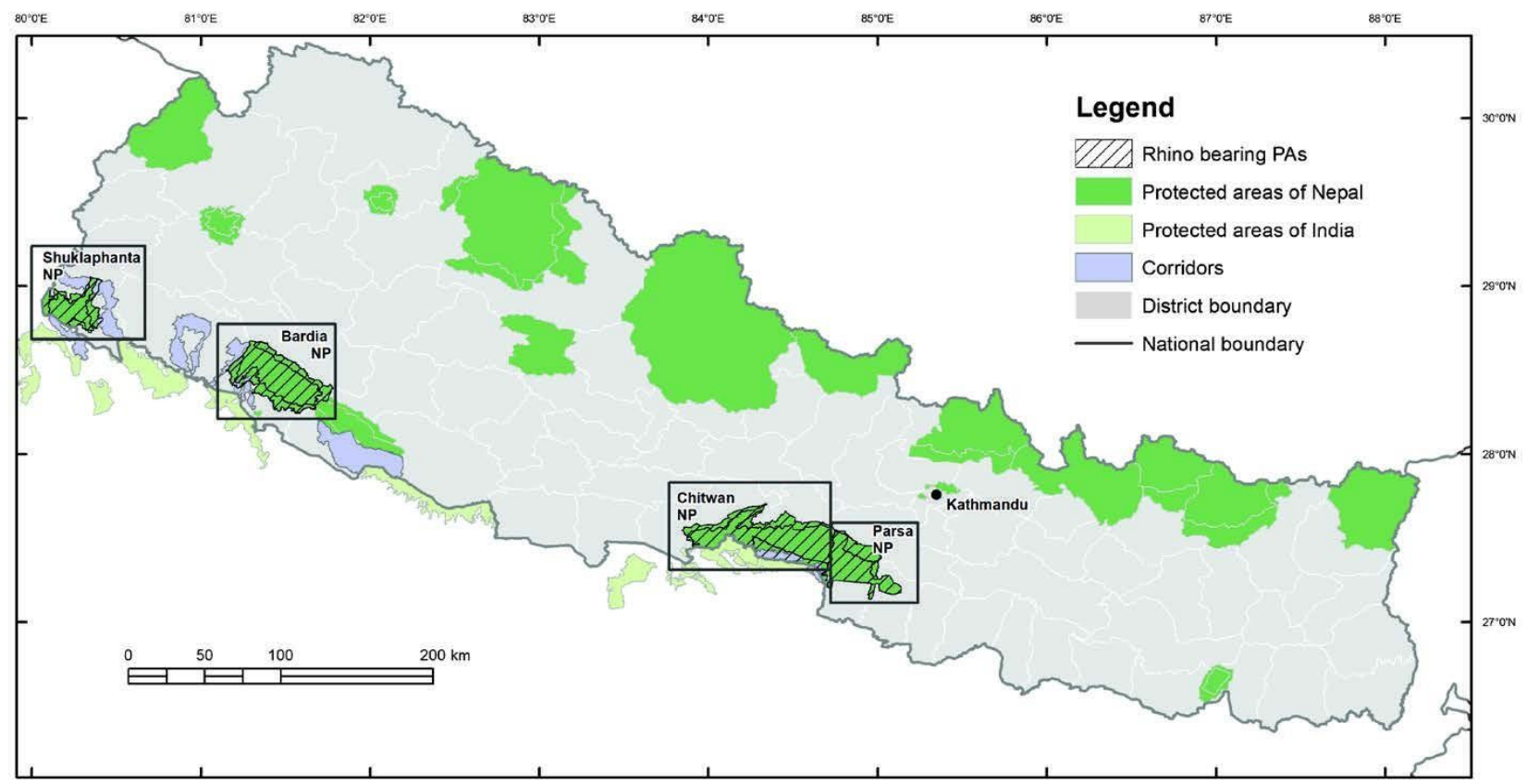

Figure 2: Map depicting rhino bearing protected areas and forest corridors of Nepal (adapted from DNPWC, 2017)

After the collapse of the Rana regime in 1950 and the eradication of malaria during the mid-1950s, Chitwan valley was opened for outsiders for settlements. Thousands of people from mid-hills were attracted by highly fertile land in Terai and large swathes of wildlife habitat were cleared for human settlements, agriculture expansion and other development activities (Caughley 1969; GoN, 2006). This not only destroyed the natural forest but also severely affected the wildlife population because of poaching. This affected mainly large mammals including one-horned rhinos and, as a result, the rhino population dropped to less than 100 during the late 1960s (Adhikari, Pradhan and Poudel, 1999; DNPWC, 2000). Recognizing the need to halt the decline of rapidly diminishing rhino population, Government of Nepal promulgated the country's first conservation law, Wildlife Protection Act 1957, for the protection of rhinoceros and their habitat. In the early 1960s, the western end of the Chitwan valley and south of the Rapti River were declared as a Rhino Sanctuary (Adhikari, Pradhan and Poudel, 1999; DNPWC, 2000). Similarly, the dramatic decline of the rhino population due to severe poaching impelled the Government to institute "Gainda Gasti", an armed Rhino Patrol Unit in 1961 and then declared the remaining prime rhino habitats, about 544 sq. km along Rapti, Narayani and Reu rivers, as the CNP in 1973. In 1973, Government of Nepal promulgated the National Parks and Wildlife Conservation Act, which provided strict protection to the endangered and protected wildlife species including rhinoceros (GoN, 1973). To prevent the extinction of rhinoceros, the Chitwan National Park was established in 1973; initially encompassing an area of 544 sq. km which was later extended to $932 \mathrm{sq}$. km in 1977 and further 
extended to 952.63 sq. $\mathrm{km}$ in 2017 and was listed as a World Heritage Site in 1984 for its high biological diversity (GoN, 1973; DNPWC, 2019). Because of ineffectiveness of the Rhino Patrol Unit, the Government of Nepal deployed Nepali Army in 1975 to intensify the wildlife patrol and surveillance (Adhikari et al., 1999). Accordingly, to conserve rare and endangered wildlife, including floral and faunal diversity, Department of National Parks and Wildlife Conservation (DNPWC) was established in 1980.

The combined effort of DNPWC and Nepal Army resulted in an increase in rhino numbers gradually. By 1988, the rhinoceros population was estimated to have reached to a total of 358 individuals (Dinerstein and Price 1991; Yonzon, 1994). In 1994, for the first time, DNPWC in collaboration with the King Mahendra Trust for Nature Conservation (now National Trust for Nature Conservation) and Resources Nepal supported by World Wide Fund for Nature (WWF) Nepal launched a Count Rhino in CNP and estimated a population size of 466 individuals. Similarly, Rhino Count in Chitwan revealed a total of 612 rhinos in Nepal in 2000. In 2005, again Rhino Count Program was conducted by the DNPWC in collaboration with National Trust for Nature Conservation (NTNC) and WWF Nepal where 446 rhinos were recorded in Nepal. Rhino population in Nepal again declined dramatically due to poaching during a decade long social and political instability after 2000. The number of rhinos in the country dropped from 446 in 2005 to 435 in 2008. Several efforts were then made to control rhino poaching resulting in gradual increase of their population as shown in the figure 3 below. The 2008 census revealed 534 rhinos in Nepal, marking an increase of 99 rhinos from the 435 estimated in census 2008. By 2015, conservation efforts saw the population grew to 645 rhinos in Nepal, marking an increase of $21 \%$ from the 534 recorded in the last census in 2011 (DNPWC, 2009, 2011 and 2015). The trend of rhino population in Nepal is illustrated below in figure 3. The rhino number clearly indicates that 545 new rhinos were added in Nepal in the past 50 years. These numbers reflect the success of conservation efforts for this species and are a result of improved rhino protection measures and management of habitat.

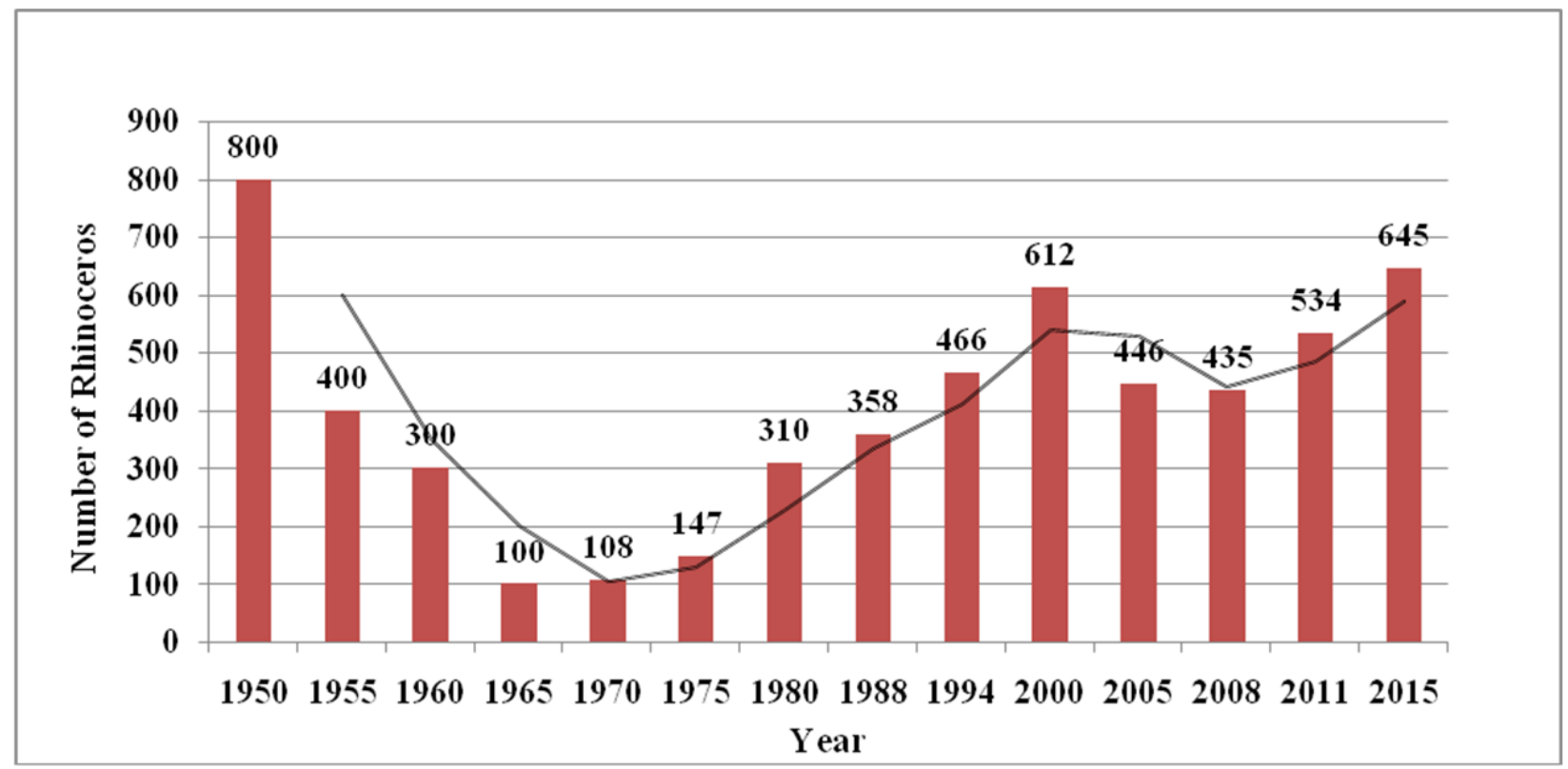

Figure 3: The population trend of Greater one-horned rhinoceros in Nepal (Source: DNPWC, 2006, 2009, 2011, 2015) 
Chitwan National Park was the only rhinoceros bearing area in Nepal till 1986. With the aim of establishing second viable population in BNP, 91 rhinoceros were translocated between 1986 and 2017 from Chitwan valley. Similarly, 9 rhinoceros were also translocated to ShNP between 2003 and 2017 to create third population in Nepal (DNPWC, 2000, 2009, 2017). Today, Chitwan National Park holds the second largest population of rhinoceros in the Indian subcontinent after Kaziranga National Park in India (Thapa et al., 2013). DNPWC, Department of Forests and Soil Conservation (DoFSC) under the Ministry of Forests and Environment in partnership with NTNC, WWF Nepal, Zoological Society of London (ZSL) and local communities conduct rhino counts at every 4-5 years to find out the population status and evaluate the effectiveness of management interventions.

Today, Nepal's protected area system covers over $23 \%$ of the total land mass of the country including 12 national parks, 1 wildlife reserves, 6 conservation areas, 1 hunting reserve and 13 buffer zones for 12 national parks and 1 wildlife reserves (DNPWC, 2019). At present, four of the six Terai protected areas encompassing an area of 2853.02 sq. km harbor 645 rhinoceros (605 in CNP, 3 in PNP, 29 in BNP and 8 in ShNP) in Nepal (DNPWC, 2017). In recent years, Nepal has achieved a new milestone in its conservation history by bringing down the number of rhino poaching incidents to zero in four years. Not a single incident of rhino poaching has been reported in 2011, making it as a landmark in the conservation history of Nepal. Since then, Nepal achieved 365 days of zero poaching of rhinos on three separate occasions in 2013, 2014 and 2015, which has given conservation officials a big reason to rejoice (DNPWC, 2015). This is a fine example of working together where all conservation partners and local communities are contributing to the conservation efforts of the Government of Nepal. Strengthening of anti-poaching mechanisms, proper management of habitat, effective coordination among all agencies concerned, strict enforcement of law and standardized monitoring and reporting systems are some of the key factors behind the success of improved and effective rhino conservation in Nepal.

\section{Conservation Threats and Challenges}

\section{Poaching and Illegal Trade of Rhino Horns}

Poaching and trade of rhino horns remains a continuous threat to the species globally. Nepal has done relatively well in addressing this threat. Between the fiscal years 2007-08 and 2016-17, 170 rhino mortalities were reported across the country. Of these, natural causes accounted for around $72 \%$, while poaching and other causes accounted for 19\% and 9\%, respectively (MoFSC, 2017). Thereafter, with a combination of actions involving multiple stakeholders, rhino poaching cases declined significantly. However, considering that the trade is fueled by demands in the international market, chances of poaching pressure escalating remains a real possibility. Therefore, poaching and trade continues to be recognized as a major threat, and combatting such wildlife crime, a priority.

\section{Habitat Loss and Degradation}

Protected areas continue to suffer from human encroachment and grazing by domestic livestock is causing serious damage. Large extents of rhinoceros habitats were converted into agriculture land during 1950s and 1960s (Laurie, 1982). At present, some forest patches in protected areas and 
buffer zones continue to suffer from human encroachment, and grazing by domestic livestock is causing serious damage in some localities. Forest encroachment in forest corridors in Terai Arc Landscape (TAL) area are some examples where large tracts of forest lands have been illegally converted into settlements and agriculture fields (MoFSC, 2015; Ghimire, 2019). Alien plant species (like Mikania micrantha) are also invading some of the grasslands on which the rhinos depend, dominating and destroying indigenous vegetation. This hinders management of rhinoceros in a meta-population approach in the long-term. Similarly, degradation of floodplain grasslands and riverine forests remains a major threat.

\section{Infrastructure Development}

The large-scale linear infrastructures including postal road (under construction), proposed railway line, high tension lines and large-scale irrigation canals pose adverse impacts on wildlife habitats including dispersal corridors. Particularly, highways fragment the habitats and obstruct the movement of animals if provisions for wildlife friendly passages were not made. East-west highway that passes through core areas (Parsa, Chitwan, Bardia and Shuklaphanta National Parks) and critical corridors (Barandabhar, Kamdi and Karnali corridors) has grave impact on wildlife movement. A significant number of wild animals including rhinos, tiger have been killed due to highway accidents (DNPWC, 2017).

\section{Human-Rhinoceros Conflicts}

Conserving mega herbivores like rhinoceros in the human dominated landscape has become a challenging job. Today, many of the protected areas with rhinos have now reached the limit of how many individuals they can support. This leads to human-rhinoceros conflict as rhinos leave the boundaries of the protected area to forage around the surrounding villages resulting in human injuries, and deaths. With the increasing rhinoceros numbers, the conflict will spread beyond the protected area boundaries as animals move outside PAs in buffer zone community forests and beyond. Recent interventions to minimize human wildlife conflicts, such as installation of solar power fences and trenches are effective against rhinoceros in few hot spots area in Chitwan, Bardia and corridors (Acharya et al., 2016; DNPWC, 2017). On the other hand, retaliatory killing by using poison and electrocution occurs occasionally.

\section{Climate Change and Natural Disaster}

Climate change is emerging as one of the prominent threats to biodiversity conservation and therefore climate smart conservation approaches have been much discussed in recent years. Although information on direct impact of climate change in wildlife species in the country are limited, regular research and monitoring on the potential adverse impact of climate change and other non-climatic disasters is imperative. However, commonly observed climate induced hazards include torrential precipitation, flashfloods; prolonged droughts and frequent forest fire are expected to increase in the coming days (DNPWC, 2017).

\section{Small/Patchy Populations}

A small population of any wildlife species is more susceptible to demographic, climatic and nonclimatic disasters, epidemic diseases and genetic stochastic events, which can impact the long-term 
survival. Small populations are often considered at risk of endangerment or extinction, and are often of conservation concern. Rhinoceros populations in Bardia and Shuklaphanta are small (Bardia < 40, and Shukla <15 individuals) and may not survive in the longer run if these populations were not built on through restocking (DNPWC, 2017). IUCN (1997) recommended having a minimum of 50 individual rhinos to establish a viable population. Realizing this, the government has initiated restocking program in both Bardia and Shuklaphanta National Parks.

\section{Invasive/Alien Species}

The spread of invasive alien plant species has immense potential to destroy prime rhino habitat. Mikania micrantha in Chitwan and Lantana camara in Bardia have heavily encroached most of potential rhino habitats and community forests in the buffer zones (DNPWC, 2009). Several invasive plants now have been established and their impacts are likely to be enormous, as losses of native flora directly influence feeding patterns of herbivore population.

\section{Wildlife Diseases}

Wildlife disease has become one of the most serious threats to the species of all genera including rhinoceros. It also has spillover effects upon both the human and animal health. Emergence of important diseases like tuberculosis in captive elephant and free-range rhinoceros had stressed important of wildlife disease investigation in Nepal. Therefore, strengthening education and training to improve veterinary support for endangered wildlife; addressing the major diseases that will benefit human, livestock and wildlife health is important.

\section{Current Efforts to Rhinoceros Conservation in Nepal}

Wildlife conservation in Nepal was initiated with the major focus on the endangered species protection and protected areas were created basically to conserve endangered species such as rhino, elephants and tigers. Most of these protected areas were managed with little emphasis on human dimension in protected area management in the past. Over the time, protected area management approach has changed from protective to participatory and from species to landscape conservation (Ghimire, 2019). Different strategies, mechanisms, programs and activities initiated over the past decade as means to conserve species, focusing on rhinos, are described briefly:

\section{Habitat Improvement}

Nepal's rhino population has increased by 45\% between the year 2005 and 2015 (DNPWC, 2015). These encouraging growths in rhino numbers reflect the success of conservation efforts for this species and are a result of improved rhino protection measures and management of habitat. Relocation of settlements in Parsa National Park and in Chitwan National Park creating additional habitat for a range of wildlife species including rhinoceros, declaration of Barandabhar, Khata and Laljhadi-Mohana forest corridors as protection forest to provide special protection to biodiversity, and evacuation of hotels from core area of national parks including Chitwan NP are major achievements under this programme (DNPWC, 2017). 


\section{Strict Law Enforcement}

The greater one-horned rhino is protected under National Park and Wildlife Conservation Act (1973) of Government of Nepal and there is a provision that illegal killing or injures, sells, purchases or transfers of rhinoceros shall be punished with a fine ranging from 500,000 to 1500,000 rupees or an imprisonment ranging from 5 years to 15 years or both (GoN, 1973). In the period of 5 years between 2011 and 2015, approximately 2400 people involved in poaching and illegal trade of wild animals were arrested by DNPWC under National Parks and Wildife Conservation Act, 1973 (MoFSC, 2017). The Government of Nepal has shown firm commitment for the conservation of biological resources by approving 10 year Strategy and Action Plan of Terai Arc Landscape (TAL) ${ }^{2}$ in 2015 . This strategic plan mainly covers the habitats of mega fauna like rhinoceros and landscape level approach to conserve mega fauna like rhinoceros, tigers and elephants etc. (MoFSC, 2015). The government of Nepal also implemented The Greater Onehorned Rhino Conservation Action Plan for Nepal (2006-2011) and its revision The Greater Onehorned Rhino Conservation Action Plan for Nepal (2017-2021) in 2017. The main goal for the rhino action plan is to preserve the Rhinoceros unicornis and strengthen the recovery of rhino population in Nepal.

\section{Institutional Set Up against Poaching and Illegal Trade}

Wildlife crime has emerged as one of the greatest threats to the survival of many wildlife species in South Asia as well as across the globe. With an urgency to address national as well as international ramifications of wildlife crime and considering inadequate resources, need of an organization with statutory powers was absolute. Therefore, as per need, the Government of Nepal has established different Wildlife Crime Control Committees (WCCC) at different levels under the Ministry of Forest and Soil Conservation to curb ongoing wildlife crimes. Wildlife Crime Control Bureau at central and district level have played significant role in making important seizures of wildlife parts and their derivatives.

\section{Active Engagement of Local Community}

The government of Nepal has been conducting various conservation programs in collaboration with different conservation partners including local community and has embraced conservation initiatives in or beyond the protected areas in favor of maintaining viable populations of rhinoceros. For effective and sustainable conservation of forest, wildlife and other natural resources, and control of poaching/illegal harvest and trade of wildlife, all the institutions, government and donor agencies involved in national park and wildlife conservation collaborated to form a community based anti-poaching unit (CBAPU) in their respective working areas. The objective of this unit is to assist the government in law enforcement, aware community on wildlife conservation and facilitate human wildlife conflict management and moreover capture wildlife criminals. In 2060, Anti-Poaching Youth Awareness Committee was formed in Nawalparasi and APYA campaign was launched in CNP. From 2007-2012, 58 CBAPUs have been formed in Buffer Zone User Committee of Makawanpur, Bara, Parsa, Chitwan, Nawalparasi, Banke, Bardiya, Surkhet and Kanchanpur.

\footnotetext{
${ }^{2}$ Terai Arc Landscape (TAL) is a landscape level trans boundary conservation initiative composed of 14 Indian and Nepalese trans-border protected ecosystems of the Terai and nearby foothills of the Himalayas.
} 
Altogether 331 CBAPUs have been established till 2015 in different parts of the country (DNPWC. 2017). This accounts the effort made by the local people in wildlife conservation.

\section{Research/Monitoring and Use of New Technology}

Regular monitoring and periodic species census are essential to update the conservation status in protected areas. Government of Nepal in collaboration with local community and conservation partners has been conducting rhino census in Nepal at an interval of 3-5 years since 1994. Since then 6 national rhino censuses were conducted to take stock of the population and devise conservation strategies (figure 3). Survey from 1994 to 2015 shows the increase of 179 rhinos in Nepal. Government of Nepal also announced that next national rhino census would take place in March 2020. Rhino census and monitoring is found to be beneficial in providing crucial information to management and scientific community for devising effective strategies for rhino conservation. Camera traps, Satellite radio collars and, most recently, Google Glass are used to track threatened species like rhinos. This strategy is observed to be very effective (DNPWC, 2017).

\section{Improved Interagency Coordination}

DNPWC and field offices are actively working to control wildlife poaching and illegal trade. Nevertheless, role of other stakeholders has been inevitable. Poachers are arrested with cooperation from other agencies, including Nepal Police. The celebration of four zero poaching years is a significant and historic achievement, which was not possible without interagency coordination. Department has started preparing anti-poaching and illegal trade strategies with concerned stakeholders believing that these strategies will facilitate the process and modality of actions for effective control of wildlife crime. Thus, poaching and illegal trade will diminish with proactive cooperation between security agencies and stakeholders.

\section{Transboundary Cooperation}

Transboundary cooperation is observed to be crucial in maintaining habitat contiguity and connectivity for meta-population of flagship species and reduce cross-border conservation threats. The enforcement of wildlife conservation legislation in Nepal remains a challenge especially because of open border. Curbing the wildlife crime demands well-coordinated multi-agency and multi-country efforts with high level of commitment and advancement. Therefore, to address various issues including poaching and illegal wildlife trade, a series of trans boundary meeting between neighboring countries, India and China, are regularly held since 1997. These have helped in collaborative action for stopping wildlife trafficking. In addition to this trilateral dialogue, bilateral meetings upon existing Memorandum of Understanding (MoUs) are also held time to time. The country has joined the South Asia Wildlife Enforcement Network (SAWEN). Thus, coordination and cooperation with neighboring countries is equally important for effective abolition of wildlife crimes, besides coordination with law enforcement agencies within the country.

\section{Restocking of Small Population}

In order to establish a viable population in BNP, a breeding population in ShNP and to safeguard the isolated Chitwan population of this endangered species from demographic/stochastic events, 
poaching and natural calamities such as flood, fire and epidemics a successful translocation expedition of 100 individual rhinos were translocated from CNP and reintroduced into BNP (91) and in ShNP (9) between 1986 and 2017 (DNPWC, 2019). The expedition is an important step towards creating a second viable population in the western complex of TAL comprising BNP and ShNP.

\section{Achieving Zero Poaching}

With alarming rates of poaching and rhino trade, both national and international conservation communities came together for immediate action to secure the future of rhinos. The initiation by Ministry of Forests and Environment, Department of National Parks and Wildlife Conservation and Department of Forest and Soil Conservation together with other key stakeholders attempted to combat rhino poaching in Nepal. As a result, not a single rhino was hunted for trade purpose in 2011, making it as a landmark in the conservation history of Nepal. Thereafter, Nepal achieved 365 days of zero poaching of rhinos on three separate occasions since 2011 (DNPWC, 2011, 2015).

\section{Conclusion}

The rhinoceros are of special interest for conservation for their role in maintaining the biodiversity. Once ranged throughout the entire stretch of the Indo-Gangetic Plain, now they are restricted to few protected areas in Nepal and India. Conservation efforts boosted the population and their numbers are now rising again and reach over 600 individuals in Nepal. The encouraging growth in rhino numbers reflects the success of conservation efforts for this species.

A result of joint effort between Government of Nepal, conservation partners and community participation, Nepal has won widespread praise from international conservationists. This applies to conservation, an evolving practice that does not take place in a void, but rather takes into account myriad of institutions, professionals, law enforcement agencies, and local communities. Yet, conservation in an ever-evolving world demands long term persistent efforts. Despite commendable successes, threats to rhinos from poaching, habitat loss and fragmentation, humanrhinoceros conflicts, climate change, and decrease in grasslands persist even today. Hence, reflecting on past success and learning from failures, actions and strategies need to be adapted for the long-term survival of this valuable species.

\section{References}

Acharya, K.P., Paudel, P.K., Neupane, P.R. and Kohl, M. (2016). Human-Wildlife Conflicts in Nepal: Patterns of Human Fatalities and Injuries caused by Large Mammals, PLoSONE 11 (9): e0161717.

Adhikari, T.R., Pradhan, N.M.B. and Poudel, N. (1999). A Strategy to combat poaching in Chitwan Valley. A report presented to Department of National Parks and Wildlife Conservation, Nepal.

Amin, R., Okita-Ouma. B., Aadcock, K., Emslie, R.H., Mulama, M. and Pearce-Kelly, P. (2006). An integrated management strategy for the conservation of Eastern black rhinoceros (Diceros bicornis michaeli) in Kenya. International Zoo Yearbook, 40: 118-129. 
Doi: https://doi.org/10.33002/nr2581.6853.03011

Caughley, G. (1969). Wildlife and recreation in the Trishuli watershed and other areas in Nepal. HMG/FAO/UNDP Trishuli Watershed Development Project, Project Report No 6, Kathmandu, Nepal.

Dinerstein, E. and Price, L. (1991). Demography and habitat use by greater one-horned rhinoceros in Nepal. Journal of Wildlife Management, 55: 401-411.

Dinerstein, E. (2003). The return of the unicorns: the natural history and conservation of the greater one-horned rhinoceros. New York: Columbia Press. 316 pp.

DNPWC (2000). Rhino count 2000 initial report. Department of National Parks and Wildlife Conservation (DNPWC), Kathmandu, Nepal

DNPWC (2009). The Status and Distribution of The Greater One-Horned Rhino in Nepal. Department of National Parks and Wildlife Conservation (DNPWC), Kathmandu, Nepal.

DNPWC (2011). The status and distribution of the greater one-horned rhino in Nepal. Department of National Parks and Wildlife Conservation (DNPWC), Kathmandu, Nepal.

DNPWC (2015). National Rhino Count 2015. Department of National Parks and Wildlife Conservation (DNPWC), Kathmandu, Nepal.

DNPWC (2016). Annual progress report. Department of National Parks and Wildlife Conservation (DNPWC), Kathmandu, Nepal.

DNPWC (2017). The Greater One-horned Rhinoceros Conservation Action Plan for Nepal (20172021). Department of National Parks and Wildlife Conservation (DNPWC), Kathmandu, Nepal.

DNPWC (2019). Protected Areas of Nepal. Department of National Parks and Wildlife Conservation (DNPWC), 2018. Government of Nepal, Ministry of Forests and Soil Conservation, Singhdurbar, Kathmandu, Nepal.

Emslie, R. (2012). Ceratotherium simum. The IUCN Red List of Threatened Species 2012: e.T4185A16980466.http://dx.doi.org/10.2305/IUCN.UK.2012.RLTS.T4185A16980466.e n. Downloaded on 17 July 2019.

Ghimire, P. (2019). Landscape Level Efforts to Biodiversity Conservation in Nepal: A Review of Current Approach and Lessons Learned. Grassroots Journal of Natural Resources, 2(3): 16-24. Doi: https://doi.org/10.33002/nr2581.6853.02032

GoN (1973). National Park and Wildlife Conservation (NPWC) Act, 1973. The Nepal Law Commission, Government of Nepal, Kathmandu, Nepal.

GoN (2006). The Greater One-Horned Rhinoceros Conservation Action Plan for Nepal (20062011), Government of Nepal (GoN), Ministry of Forests and Soil Conservation, Department of National Parks and Wildlife Conservation, Kathmandu, Nepal.

IUCN (1997). Status Survey and Conservation Action Plan: Asian Rhinos. Thomas J. Foose and Nico van Strien (eds.). IUCN/SSC Asian Rhino Specialist Group. Gland, Switzerland.

IUCN (2008). IUCN Red List Categories. IUCN Species Survival Commission. IUCN, Gland, Switzerland.

IUCN (2013). International Union for Conservation of Nature. https://www.iucn.org/content/african-rhinos-won\%E2\%80\%99t-hold-out-much-longeriucn-expertswarn

Laurie, W.A. (1978). The ecology and behavior of the greater one-horned rhinoceros. $\mathrm{PhD}$ Dissertation. University of Cambridge, Cambridge, UK.

Laurie, W.A. (1982). Behavioral ecology of the Greater One-horned Rhinoceros (Rhinoceros unicornis). Journal of Zoological Society of London, 196: 307-341.

MoFSC (2015). Strategy and Action Plan 2015-2025, Terai Arc Landscape, Nepal. Ministry of Forests and Soil Conservation (MoFSC), Singha Durbar, Kathmandu, Nepal. 
MoFSC (2017). Annual Report 2016-2017. Department of National Parks and Wildlife Conservation (DNPWC). Government of Nepal, Ministry of Forests and Soil Conservation (MoFSC), Babarmahal, Kathmandu, Nepal 2017.

Pant, G., Maraseni, T., Apan, A. and Allen, B.L. (2019). Trends and current state of research on greater one-horned rhinoceros (Rhinoceros unicornis): A systematic review of the literature over a period of 33 years (1985-2018). Science of The Total Environment, 710(25): 136349. https://doi.org/10.1016/j.scitotenv.2019.136349.

Pradhan, N.M.B., Wegge, P., Moe, S.R. and Shrestha, A.K. (2008). Feeding ecology of two sympatric mega herbivores: Asian elephant (Elephas maximus) and greater one-horned rhinoceros (Rhinoceros unicornis) in lowland Nepal. Wildlife Biology, 14: 147-154.

Rookmaaker, K., Sharma, A., Bose, J., Thapa, K., Dutta, D., Jeffries, B., Williams, A.C., Ghose, D., Gupta, M. and S. Tornikoski (2016). The Greater One-horned Rhino: Past, Present and Future. WWF, Gland, Switzerland.

Sedhain, J. and Adhikary A. (2016). Rhino Conflict: Local People's Adaptation to Impacts of Rhino. Journal of Forest and Livelihood, 14(1): 53-66.

Subedi, N. (2012). Effect of Mikania micrantha on the demography, habitat use, and nutrition of Greater One-horned Rhinoceros in Chitwan National Park, Nepal. PhD Thesis. Forest Research Institute University, Dehradun.

Thapa, K., Nepal, S., Thapa, G., Bhatta, S.R. and Wikramanayake, E. (2013). Past, present and future conservation of the greater one-horned rhinoceros (Rhinoceros unicornis) in Nepal. Oryx, 47: 345-351.

Yonzon, P. (1994). Count Rhino 1994. Report Series No. 10, WWF Nepal Program, Kathmandu. 